\title{
The matrix metalloproteinase and insulin-like growth factor system in oral cancer - a prospective clinical study
}

\section{Eik Schiegnitz' \\ Peer W Kämmerer ${ }^{2}$ \\ Holger Schön' \\ Christoph Gülle' \\ Manfred Berres ${ }^{3,4}$ \\ Keyvan Sagheb' \\ Bilal Al-Nawas ${ }^{5}$}

'Department of Oral and Maxillofacial Surgery, Plastic Surgery, University

Medical Center, Johannes Gutenberg University of Mainz, Mainz,

${ }^{2}$ Department of Oral and Maxillofacial Surgery, Plastic Surgery, University Medical Centre Rostock, Rostock, ${ }^{3}$ Department of Mathematics and Technology, University of Applied Sciences Koblenz, Remagen, ${ }^{4}$ Institute of Medical Biometry, Epidemiology and Informatics, Johannes Gutenberg University of Mainz, Mainz,

${ }^{5}$ Department of Oral and Maxillofacial Surgery, Plastic Surgery, University Medical Centre, Martin-Luther University Halle, Halle, Germany

Correspondence: Eik Schiegnitz Department of Oral and Maxillofacial Surgery, Plastic Surgery, University Medical Centre, Johannes Gutenberg University of Mainz, Augustusplatz 2,

55।3I Mainz, Germany

Tel +49 6I3I I7 5084

Fax +49 6131176602

Email eik.schiegnitz@unimedizin-mainz.de
This article was published in the following Dove Press journal:

OncoTargets and Therapy

24 October 2017

Number of times this article has been viewed

Aim: The absence of reliable single serum biomarkers for oral premalignant lesion (OPL) and oral squamous cell carcinoma (OSCC) limits early diagnosis, monitoring of advanced disease, and prediction of prognosis.

Methods: In this prospective study, serum levels of matrix metalloproteinase (MMP)-2, MMP-3, MMP-13, insulin-like growth factor (IGF)-1, and IGF-binding protein (IGFBP)-3 were measured in 81 untreated OSCC patients, 49 healthy subjects, and 75 individuals with OPLs, and correlated with clinicopathological parameters.

Results: Serum levels of MMP-3 were significantly higher in OSCC patients compared to healthy subjects $(p=0.004)$. Mean IGF-1 and IGFBP-3 levels in OSCC patients were significantly lower in healthy subjects $(p=0.001$ and $p<0.001)$. OSCC patients with an IGF-1 serum value $<130 \mathrm{ng} / \mathrm{mL}$ (median) showed a significantly lower survival rate compared to $\geq 130 \mathrm{ng} / \mathrm{mL}$ $(p=0.049)$. Combined use of IGF-1 $(<130 \mathrm{ng} / \mathrm{mL})$ and IGFBP-3 $(<3.1 \mu \mathrm{g} / \mathrm{mL})$ resulted in a significantly lower 12-month cumulative survival compared to the complementary set $(78.5 \%$ vs $93.8 \%$; $p=0.031$ ). There was a significantly positive correlation between IGF-1 and IGFBP-3 serum values $\left(r_{\mathrm{s}}=0.625, p<0.001\right)$.

Conclusion: This study shows that IGF-1 and IGFBP-3 have a vital role in the pathogenesis of OSCC and indicates for the first time that IGF-1 and IGFBP-3 in combination may be applied as potential tools for prognosis of OSCC.

Keywords: oral cancer, OSCC, oral premalignant lesion, serum biomarker, prognosis, IGF, MMP

\section{Introduction}

Oral squamous cell carcinoma (OSCC) poses a major health problem in the world and $\sim 600,000$ cases are diagnosed every year. ${ }^{1}$ Although advancements in surgery techniques, radiation, and chemotherapy protocols have increased the local control of OSCC, the overall survival rates have not improved significantly over the last 3 decades and remain at a low level of $\sim 50 \%-60 \%{ }^{2}$ However, when oral cancer is diagnosed early in stages I-II, the survival of the patients rises from $60 \%$ to $80 \%{ }^{3}$ Therefore, early detection is of vital importance for the patients. There is clear evidence that the annual rate of malignant transformation of oral premalignant lesions (OPLs) differs from $0 \%$ to $20 \%$ in $1-30$ years. ${ }^{4,5}$ Tumorigenesis and the malignant transformation from OPL to OSCC is a highly complex regulated process and depends on multiple steps. ${ }^{6}$ In this context, angiogenesis is described as one of the most important mechanisms and has been identified to play a crucial role in progression and invasiveness of most tumors. ${ }^{7-9}$ Angiogenesis depends on pro- and anti-angiogenic molecules, which are expressed by normal and malignant cells. Recently described pro- and anti-angiogenic factors were matrix metalloproteinases 
(MMPs) and insulin-like growth factors (IGFs). ${ }^{10}$ Analysis of these molecules could be highly useful for the early detection as well as for the determination of the individual prognosis of (pre-)malignant lesions in the oral cavity. ${ }^{11}$

MMPs belong to a zinc-dependent endopeptidase superfamily ${ }^{12,13}$ that is distinct from other proteinases by the presence of a histidine sequence pattern. ${ }^{14}$ The MMP family consists of 23 currently known zinc-containing enzymes and is classified into five groups based on their substrate and molecular structure: collagenases, gelatinases, stromelysins, membrane type MMPs and others. ${ }^{13-15}$ MMPs are multifunctional proteolytic enzymes, able to cleave extracellular matrix components like collagens and fibronectin, growth factors, cytokines, and cell receptors. ${ }^{14}$ In cancer, these MMPs regulate cancer cell growth, differentiation, apoptosis, migration, invasion, and regulation of tumor angiogenesis and immune surveillance. ${ }^{14,16}$ With regard to gene expression and immunohistochemistry level, an involvement of MMP-1, MMP-2, MMP-9, and MMP-10 in OSCC oncogenesis was seen. ${ }^{17-20}$ As serum markers in OSCC, MMP-2, MMP-3, and MMP-13 were previously described. ${ }^{13,21-23}$

The IGF system comprises a multifaceted network of ligands (IGF-1 and -2), their related receptors (IGFR-1 and -2), IGF-binding proteins (IGFBP1-6), and IGFBP proteases. ${ }^{10,24}$ Regarding carcinogenesis, the IGF family members regulate proliferation and inhibition of cell apoptosis, influence cell transformation through the synthesis of numerous regulatory proteins and control clonal expansion and metastases of cells. ${ }^{25}$ IGF-binding proteins (IGFBPs) modulate the bioavailability of IGFs and regulate the interaction between IGFs and cell-surface receptors. In this context, IGFBP-3 seems to have the principal role in OSCC carcinogenesis. ${ }^{26,27}$

There are numerous studies indicating an important role of MMP-2, MMP-3, MMP-13, IGF-1, and IGFBP-3 in different malignancies. However, to the best of our knowledge, there is no report available on serum status of these proteins in patients with OPL and OSCC. Therefore, the aim of this study was to evaluate the serum level of these proteins in a prospective multi-biomarker approach and correlate it with clinicopathological parameters.

\section{Materials and methods}

\section{Subjects and sample preparation}

This prospective clinical study includes 81 patients with histopathologically proven primary OSCC, 75 noncancerous patients with OPLs, and 49 healthy individuals. The patients were treated in the Department of Oral and Maxillofacial Surgery (University Medical Centre Mainz, Germany).
The OPL group consisted of noncancerous patients with oral leukoplakia and/or erythroplakia and lichen. All sera were collected from patients at the time of diagnosis and prior to surgery or radiation therapy. The control group was recruited from patients undergoing routine dentoalveolar surgery. Main inclusion criterion for the control group was the absence of any history of malignancy and infectious disease. All patients provided informed consent before participating in the study. The study was conducted in accordance with the Helsinki Declaration of 1975 as revised in 2000. The protocol was approved by the local ethics committee (Landesärztekammer Rheinland-Pfalz, Ethik-Komission, number 837.524 .15 (10292)). The mean ages of OSCC patients, OPL patients, and healthy controls were $68 \pm 11.9$ years (range $34-90$ ), 61 \pm 12.8 years (range 24-81), and 58 \pm 14.0 years (range 26-93), respectively. Sites of tumor were buccal mucosa $(14.8 \%)$, maxilla $(11.1 \%)$, mandible (29.6\%), tongue (14.8\%), floor of mouth $(16.8 \%)$, and palate (9.9\%). According to T-Grade, 33.3\% were T1, $24.7 \%$ were $\mathrm{T} 2,9.9 \%$ were $\mathrm{T} 3$, and $32.1 \%$ were $\mathrm{T} 4$ tumors; $58 \%$ of the cases had no lymph node metastasis (N0); $13.6 \%$ were graded N1; and $28.4 \%$ were graded N2. One patient $(1.2 \%)$ showed distant metastases (M1).

\section{Assay}

Sandwich enzyme-linked immunosorbent assay (ELISA) was used for the quantification of MMP-2, MMP-3, and MMP-13 levels in blood samples with the DuoSets ELISA for humans (R\&D Systems, Minneapolis, MN, USA) following the manufacturer's protocol. IGF-1 and IGFBP-3 were measured using a Chemiluminescence Immunoassay (IMMULITE ${ }^{\circledR}$ 1000; Siemens Healthineers, Erlangen, Germany). Venous blood was allowed to clot for 30 minutes at room temperature and was then centrifuged for 10 minutes at 3,000× $g$. Serum samples were stored at $-80^{\circ} \mathrm{C}$ until further processing. All measurements were made in triplicates. Examiners were blinded to clinical results.

\section{Statistical analysis}

Statistical analysis was performed with univariate tests by using the software package of IBM SPSS Statistics 20.0 for Windows (IBM Corporation, Armonk, NY, USA). As serum levels of the investigated biomarkers were skewed to the right, logarithmic transformed values were analyzed. Survival curves were plotted by using the Kaplan-Meier method and compared using the univariate log rank test as described earlier. ${ }^{28}$ For analysis of diagnostic accuracy, receiver operating characteristic (ROC) curves were used. For examination 
of the correlation between serum values, Spearman's rank-order correlation was performed. $P$-values $<0.05$ are described as "statistically significant," although no adjustment for multiple tests has been applied.

\section{Results}

\section{Serum levels in association with clinicopathological data}

The serum levels of MMP-2, MMP-3, MMP-13, IGF-1, and IGFBP-3 in association with clinicopathological data are described in Table 1. Serum levels of MMP-3 were significantly higher in OSCC patients compared to healthy controls ( $p=0.004)$. Serum levels of IGF-1 in OPL and OSCC patients were significantly lower than IGF-1 serum levels of healthy controls $(p=0.018$ and $p=0.001)$. Serum IGFBP-3 levels were significantly lower in OSCC patients compared to healthy controls $(p<0.001)$. Serum levels in relation to T-Grade (T1/T2 vs T3/T4) and lymph node involvement (N0 vs $\mathrm{N}+$ ) showed the following $p$-values (T-Grade: MMP-2: $p=0.002$; MMP-3: $p=0.953$, MMP-13: $p=0.234$, IGF-1: $p=0.732$, and IGFBP-3: $p=0.131$; lymph node involvement: MMP-2: $p=0.638$; MMP-3: $p=0.299$, MMP-13: $p=0.326$, IGF-1: $p=0.385$, and IGFBP-3: $p=0.103$ ).

\section{Serum levels in association with tumor recurrence, metastasis, and prognosis}

In our examination of the relationship between serum levels of MMP-2, MMP-3, MMP-13, IGF-1, and IGFBP-3 and tumor recurrence, metastasis, or prognosis, the serum concentrations were divided into two groups. We chose the median of all OSCC serum values as cutoff. None of the investigated biomarkers had a significant influence on tumor recurrence or metastasis. OSCC patients with an IGF-1 serum value $<130 \mathrm{ng} / \mathrm{mL}$ showed a significant lower survival rate compared to OSCC patients with an IGF-1 serum value $\geq 130 \mathrm{ng} / \mathrm{mL}$ ( $p=0.043$; Figure 1). Cumulative survival after 12 months was $80.8 \%$ for patients with IGF-1 serum value $<130 \mathrm{ng} / \mathrm{mL}$ and $94.9 \%$ for patients with IGF-1 serum value $\geq 130 \mathrm{ng} / \mathrm{mL}$. OSCC patients with
IGFBP-3 serum value $<3.1 \mu \mathrm{g} / \mathrm{mL}$ had a lower survival rate compared to OSCC patients with IGFBP-3 serum value $\geq 3.1 \mu \mathrm{g} / \mathrm{mL}$, however not statistically significant ( $p=0.157$; Figure 2 ). Twelve-months cumulative survival was $82.9 \%$ for patients with IGFBP-3 $<3.1 \mu \mathrm{g} / \mathrm{mL}$ and $92.7 \%$ for patients with IGFBP-3 $\geq 3.1 \mu \mathrm{g} / \mathrm{mL}$. Combined use of IGF-1 $(<130 \mathrm{ng} / \mathrm{mL})$ and IGFBP-3 $(<3.1 \mu \mathrm{g} / \mathrm{mL})$ resulted in a significant lower 12-month cumulative survival compared to the complementary set (78.5\% vs $93.8 \% ; p=0.031$; Figure 3 ).

\section{Determination of the diagnostic accuracy}

To examine the performance of the investigated biomarkers for diagnosis of OSCC versus healthy controls and OPL patients, ROC curves were determined by plotting sensitivity versus specificity. The respective area under the ROC curve (AUC) as a measure of diagnostic performance in the discrimination of OSCC patients versus healthy controls is displayed in Table 2. For single biomarker analysis, only IGFBP-3 showed a good diagnostic accuracy with an AUC of 0.724. AUC for the discrimination of OSCC patients versus OPL patients is indicated in Table 3. None of the investigated biomarkers showed a good diagnostic accuracy in this context.

\section{Correlation of serum values}

A Spearman's rank-order correlation was performed to determine the relationship between the serum values of the different biomarkers. There was a strong, positive correlation between IGF-1 and IGFBP-3 values, which was statistically significant $\left(r_{\mathrm{s}}=0.625, p<0.001\right.$; Figure 4$)$.

\section{Discussion}

Many previous studies have demonstrated altered expression of cytokines and/or growth factors in tumor tissues or sera of patients with oral carcinoma. ${ }^{29,30}$ However, relevance of this altered expression on tumor diagnosis and influence on tumor recurrence and patient prognosis remain unclear. The aim of this prospective study was to investigate serum levels of MMP-2, MMP-3, MMP-13, IGF-1, and IGFBP-3 in healthy

Table I Clinicopathological features and biomarker serum levels of the included subjects

\begin{tabular}{|c|c|c|c|c|c|c|c|c|c|c|c|}
\hline Characteristics & $\begin{array}{l}\text { Patients } \\
\text { (n) }\end{array}$ & $\begin{array}{l}\text { MMP-2 } \\
\text { (ng/mL) }\end{array}$ & $p$-value & $\begin{array}{l}\text { MMP-3 } \\
\text { (ng/mL) }\end{array}$ & $p$-value & $\begin{array}{l}\text { MMP-I3 } \\
(\mathrm{pg} / \mathrm{mL})\end{array}$ & $p$-value & $\begin{array}{l}\text { IGF-I } \\
\text { (pg/mL) }\end{array}$ & $p$-value & $\begin{array}{l}\text { IGFBP-3 } \\
(\mu \mathrm{g} / \mathrm{mL})\end{array}$ & $p$-value \\
\hline Controls & 49 & $100 \pm 34$ & & $10.7 \pm 8.2$ & & $189 \pm 372$ & & $16 \mid \pm 59$ & & $4.0 \pm 1.0$ & \\
\hline OPL patients & 75 & $97 \pm 26$ & 0.864 & $10.2 \pm 11.2$ & 0.932 & $556 \pm 910$ & 0.12 & $136 \pm 53$ & 0.018 & $3.7 \pm 0.9$ & 0.147 \\
\hline OSCC patients & 81 & $114 \pm 48$ & 0.198 & $12.3 \pm 6.9$ & 0.004 & $584 \pm 2,423$ & 0.612 & $|29 \pm 5|$ & 0.001 & $3.2 \pm 1.1$ & $<0.001$ \\
\hline Global $p$-value & & & 0.209 & & 0.001 & & 0.055 & & 0.004 & & $<0.001$ \\
\hline
\end{tabular}

Abbreviations: MMP, matrix metalloproteinase; IGF, insulin-like growth factor; IGFBP, IGF-binding protein; OPL, oral premalignant lesion; OSCC, oral squamous cell carcinoma. 


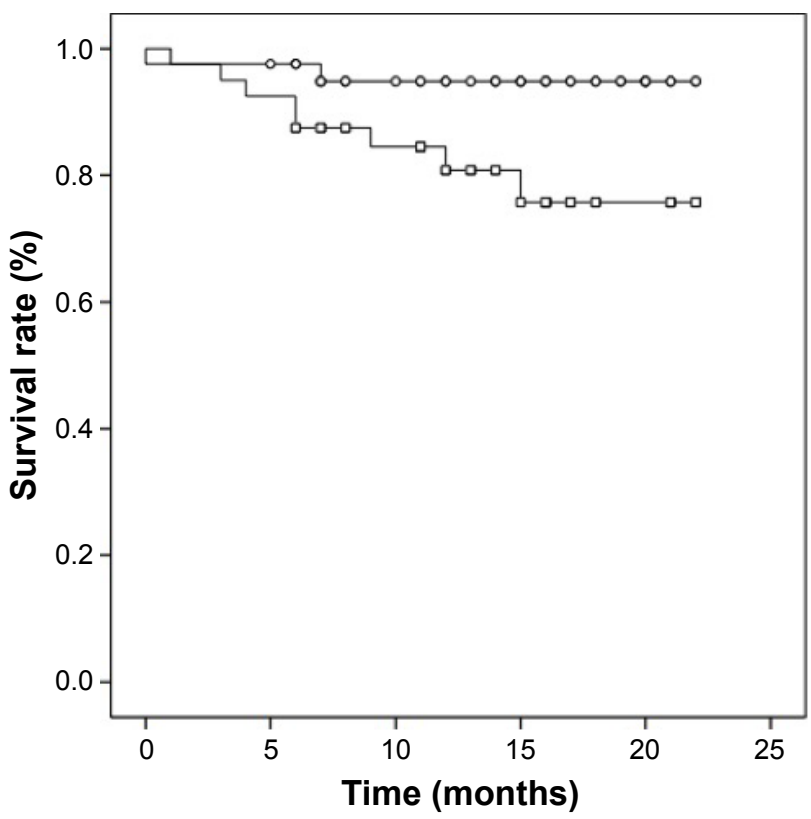

Figure I Survival rate of OSCC patients with IGF-I serum values $\geq 130 \mathrm{ng} / \mathrm{mL}$ (circles, $\mathrm{n}=4 \mathrm{I}$ ) and with IGF-I serum values $<130 \mathrm{ng} / \mathrm{mL}$ (squares, $\mathrm{n}=40 ; p=0.043$ ). Abbreviations: IGF, insulin-like growth factor; OSCC, oral squamous cell carcinoma.

controls, patients with OPL, and patients with OSCC and correlate them with clinicopathological parameters.

MMP-2 is a gelatinase A, and in contrast to most MMP family members, activation of this protein can occur on the cell membrane. ${ }^{31} \mathrm{MMP}-2$ is correlated with poor prognosis in

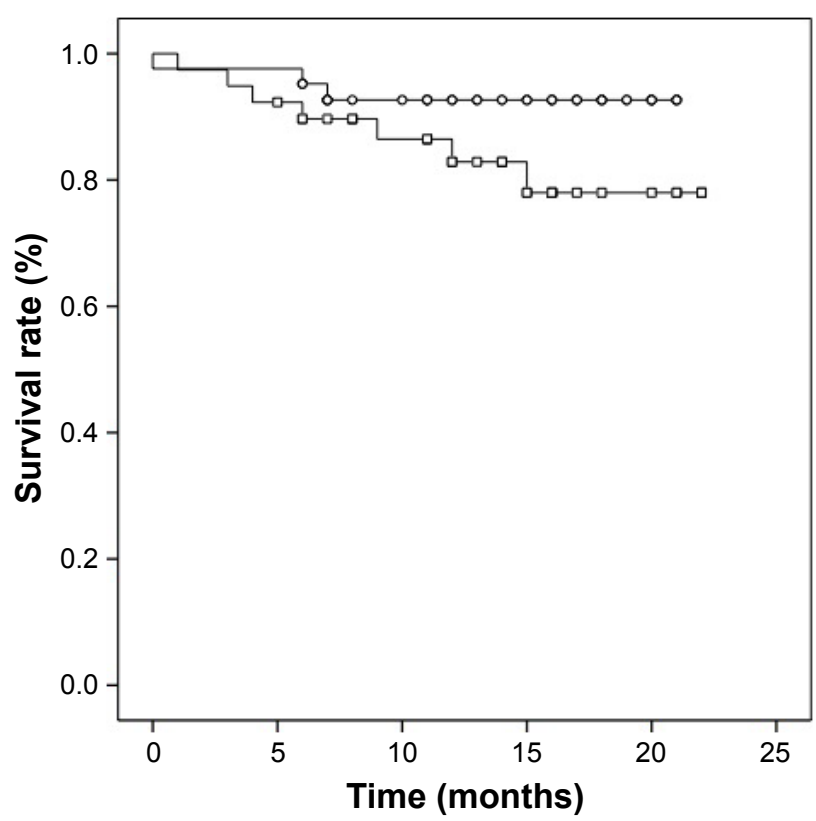

Figure 2 Survival rate of OSCC patients with IGFBP-3 serum values $\geq 3.1 \mu \mathrm{g} / \mathrm{mL}$ (circles, $\mathrm{n}=42$ ) and with IGFBP- 3 serum values $<3.1 \mu \mathrm{g} / \mathrm{mL}$ (squares, $\mathrm{n}=39 ; p=0.149$ ). Abbreviations: IGF, insulin-like growth factor; IGFBP, IGF-binding protein; OSCC, oral squamous cell carcinoma.

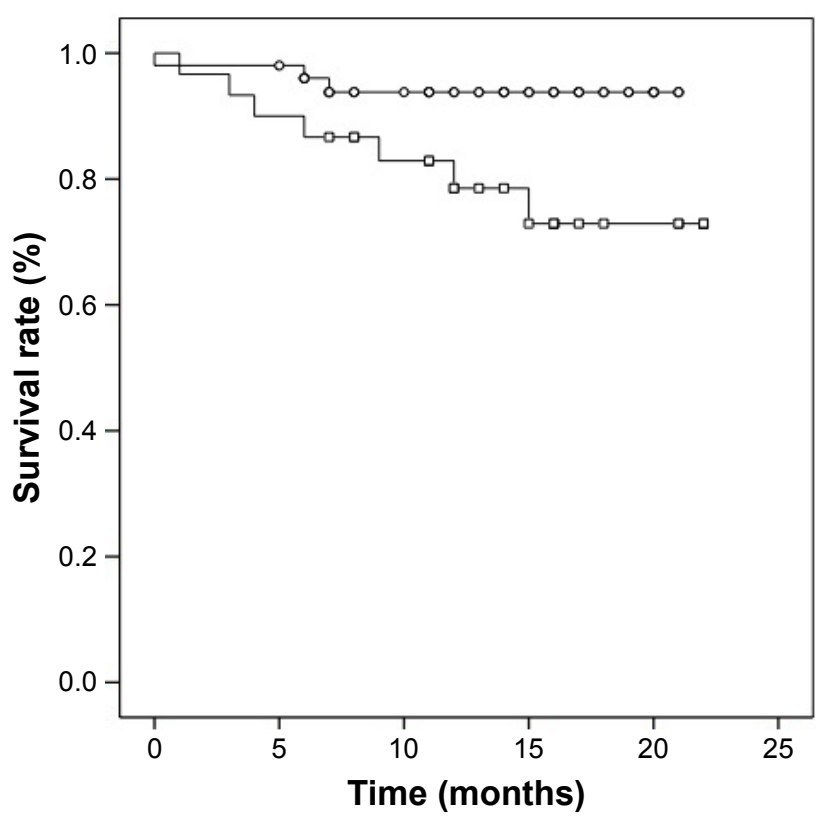

Figure 3 Survival rate of OSCC patients with IGF-I ( $\geq 130 \mathrm{ng} / \mathrm{mL})$ and IGFBP-3 $(\geq 3.1 \mu \mathrm{g} / \mathrm{mL}$ ) serum values (circles, $\mathrm{n}=5 \mathrm{I})$ and with IGF-I $(<130 \mathrm{ng} / \mathrm{mL})$ and IGFBP-3 $(<3.1 \mu \mathrm{g} / \mathrm{mL}$ ) serum values (squares, $\mathrm{n}=30 ; p=0.031$ ).

Abbreviations: IGF, insulin-like growth factor; IGFBP, IGF-binding protein; OSCC, oral squamous cell carcinoma.

many cancer types and was associated with tumor invasion and lymph node metastasis by mediating the degradation of extracellular matrix components. ${ }^{31,32}$ In our patient collective, higher MMP-2 serum values were found in OSCC patients compared to healthy controls, however not statistically significant. Lotfi et al showed significantly increased serum levels of MMP-2 in 20 OSCC patients compared to 20 healthy subjects. ${ }^{23}$ In a study by Patel et al, serum MMP-2 values failed to show any correlation with disease status during follow-up period. ${ }^{33}$

MMP-3 is able to degrade a multitude of molecules including collagen type II, IV, IX, X, and XI, fibronectin, gelatins, elastin, proteoglycanase, E-cadherin, and osteopontin. ${ }^{15,34,35}$

Table 2 Area under the curve for the discrimination of OSCC patients versus healthy controls

\begin{tabular}{llll}
\hline Biomarker & AUC & $\begin{array}{l}\text { Asymptotic 95\% confidence } \\
\text { interval }\end{array}$ \\
\cline { 3 - 4 } & & Lower bound & Upper bound \\
\hline MMP-2 & 0.586 & 0.488 & 0.683 \\
MMP-3 & 0.667 & 0.568 & 0.765 \\
MMP-I3 & 0.539 & 0.438 & 0.640 \\
IGF-I* & 0.648 & 0.550 & 0.746 \\
IGFBP-3* & 0.724 & 0.636 & 0.812 \\
\hline
\end{tabular}

Note: *As low IGF-I and IGFBP-3 serum values are associated with OSCC, negative IGF-I and IGFBP-3 values were used.

Abbreviations: AUC, area under the curve; MMP, matrix metalloproteinase; IGF, insulin-like growth factor; IGFBP, IGF-binding protein; OSCC, oral squamous cell carcinoma. 
Table 3 Area under the curve for the discrimination of OSCC patients versus OPL patients

\begin{tabular}{llll}
\hline Biomarker & AUC & \multicolumn{2}{l}{$\begin{array}{l}\text { Asymptotic 95\% confidence } \\
\text { interval }\end{array}$} \\
\cline { 3 - 4 } & & Lower bound & Upper bound \\
\hline MMP-2 & 0.602 & $0.5 I I$ & 0.694 \\
MMP-3 & 0.670 & 0.585 & 0.756 \\
MMP-I3 & 0.600 & $0.5 I I$ & 0.690 \\
IGF-I* & 0.522 & 0.431 & 0.613 \\
IGFBP-3* & 0.661 & 0.574 & 0.747 \\
\hline
\end{tabular}

Note: *Low IGF-I and IGFBP-3 serum values are associated with OSCC.

Abbreviations: AUC, area under the curve; MMP, matrix metalloproteinase; IGF, insulin-like growth factor; IGFBP, IGF-binding protein; OPL, oral premalignant lesion; OSCC, oral squamous cell carcinoma.

Previous studies described the role of MMP-3 in apoptosis induction, angiogenesis regulation, invasion, and metastasis in cancer. ${ }^{15}$ In our study, serum levels of MMP-3 were significantly higher in OSCC patients compared to healthy controls. Furthermore, Agha-Hosseini et al showed increased MMP-3 serum concentrations from the reticular form of OPL to erosive form of OPL, and further to low stage of OSCC and advanced stage of OSCC. ${ }^{22}$ Andisheh-Tadbir et $\mathrm{al}^{36}$ indicated significantly elevated serum MMP-3 level in OSCC patients versus healthy controls. However, a correlation of serum MMP-3 concentration with clinicopathologic features such as tumor stage, tumor size, nodal status, and histological grade was not seen.

MMP-13 is known as collagenase-3, and increased expression of MMP-13 has been associated with tumor behavior and prognosis. ${ }^{37}$ Studies indicated that MMP-13 is secreted directly by cancer tissue and indirectly promotes tumor angiogenesis. ${ }^{12,38}$ In the investigated subjects, higher

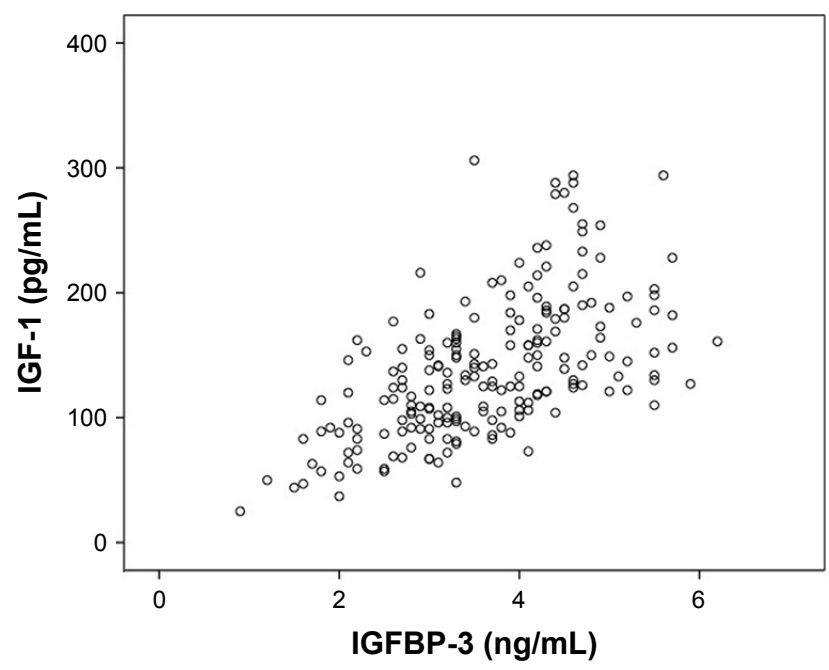

Figure 4 Correlation between serum IGF-I (pg/mL) and IGFBP-3 $(\mathrm{ng} / \mathrm{mL})$ levels. Abbreviations: IGF, insulin-like growth factor; IGFBP, IGF-binding protein.
MMP-13 values were seen in OPL and OSCC patients compared to healthy controls, however not statistically significant. Serum values in OPL and OSCC patients were comparable as described before. ${ }^{21}$

IGF-1 and its principal binding protein IGFBP-3 are essentially involved in normal somatic growth by supporting cellular proliferation and inhibiting apoptosis. ${ }^{26}$ In addition, there is clear evidence that the IGF signaling pathway has a key role in the onset and progress of various malignant tumors and can be targeted for therapeutic intervention. ${ }^{10,25}$ To the best of our knowledge, this is the first study that shows significant lower IGF-1 serum values in OPL patients compared to healthy controls. Regarding lower levels in OSCC patients compared to healthy controls, two further clinical studies supported our results. ${ }^{26,39}$ In addition, our results indicated significant lower IGFBP-3 values in OSCC patients compared to healthy controls. Brady et al showed similar findings. ${ }^{26}$ These results implicate that IGF-1 and IGFBP-3 may help in the early detection of OSCC and could be a potential tool for screening. However, the diagnostic accuracy in ROC analysis was not sufficient. These low ROC values may be overcome in the future, if joint effects of multiple biomarkers with a cumulated ROC value are applied, as described before. ${ }^{40}$ In this way, the ROC values and diagnostic accuracy may be increased. IGF-1 and IGFBP-3 have practical advantages over other cytokines for diagnostic use. For example, no specific collection of protocols are needed, as IGF-1 is not expressed by blood cells. A possible disadvantage is that IGF-1 is also expressed in several other types of cancer. Therefore, a multibiomarker approach may be reasonable. The shown lower IGF-1 and IGFBP-3 values in OSCC seem to contradict the accepted role of IGF-1 in tumorigenesis, as an increased risk of cancer is associated with higher circulating levels of IGF-1 and IGFBP-3 in different cancers. ${ }^{26,41,42}$ This could be explained with the hypothesis that OSCC is regulated by systemic IGF-1 levels at the onset of growth. With tumor progress, an independent autocrine stimulation of the tumor occurs with low IGF-1 systemic concentrations. ${ }^{42}$ Another explanation may be that there is actually no relationship between serum values in cancer patients and healthy controls and that current technology in the detection of the molecules is insufficiently reliable or sensitive to levels of the active molecules of interest. ${ }^{26,42}$ Our results describe both IGF-1 and IGFBP-3 as new marker of prognosis of OSCC. The combination of both the factors showed the highest accuracy predicting survival. Therefore, clinical implementation of these factors in preoperative diagnosis seems to be promising and may result in a 
more aggressive surgical and adjuvant therapeutic approach. In our study, IGF-1 and IGFBP-3 levels correlated strongly with each other. These results indicate that these molecules have a strong functional interaction. The pathophysiology behind these results merits further investigation.

\section{Conclusion}

In conclusion, high MMP-3 and low IGF-1 and IGFBP-3 serum values are associated with OSCC. IGF-1 and IGFBP-3 and especially the combination of both the factors represent a novel potential prognostic tool of important clinical interest for a better risk assessment of patient survival. The promising results of these biomarkers should now be confirmed in a clinical setting with larger patient numbers, and it should be determined whether the diagnostic and prognostic utility could be further improved by combining the investigated molecules with other serum markers.

\section{Acknowledgments}

The data from this study are part of the dissertation work submitted to Johannes Gutenberg University of Mainz as part of doctoral theses of Holger Schön and Christoph Gülle. Both authors collected and processed the samples.

\section{Disclosure}

The authors report no conflicts of interest in this work.

\section{References}

1. Parkin DM, Bray F, Ferlay J, Pisani P. Global cancer statistics, 2002. CA Cancer J Clin. 2005;55(2):74-108.

2. Canto MT, Devesa SS. Oral cavity and pharynx cancer incidence rates in the United States, 1975-1998. Oral Oncol. 2002;38(6):610-617.

3. Mehrotra R, Gupta DK. Exciting new advances in oral cancer diagnosis: avenues to early detection. Head Neck Oncol. 2011;3:33.

4. Napier SS, Speight PM. Natural history of potentially malignant oral lesions and conditions: an overview of the literature. J Oral Pathol Med. 2008;37(1):1-10.

5. Ghallab NA, Shaker OG. Serum and salivary levels of chemerin and MMP-9 in oral squamous cell carcinoma and oral premalignant lesions. Clin Oral Invest. 2017;21(3):937-947.

6. Thiem DG, Schneider S, Venkatraman NT, et al. Semiquantifiable angiogenesis parameters in association with the malignant transformation of oral leukoplakia. J Oral Pathol Med. Epub 2016 Dec 30.

7. Kammerer PW, Al-Nawas B, Kalkan S, et al. Angiogenesis-related prognosis in patients with oral squamous cell carcinoma-role of the VEGF +936 C/T polymorphism. J Oral Pathol Med. 2015;44(6):429-436.

8. Kammerer PW, Toyoshima T, Eletr S, et al. Single nucleotide polymorphisms of the vascular endothelial growth factor gene associated with incidence of oral squamous cell carcinoma. J Oral Pathol Med. 2010;39(10):786-792.

9. Mohtasham N, Babakoohi S, Salehinejad J, et al. Mast cell density and angiogenesis in oral dysplastic epithelium and low- and high-grade oral squamous cell carcinoma. Acta Odontol Scand. 2010;68(5):300-304.

10. van Beijnum JR, Pieters W, Nowak-Sliwinska P, Griffioen AW. Insulinlike growth factor axis targeting in cancer and tumour angiogenesis - the missing link. Biol Rev Camb Philos Soc. 2017;92(3):1755-1768.
11. Schiegnitz E, Kammerer PW, Rode K, Schorn T, Brieger J, Al-Nawas B. Growth differentiation factor 15 as a radiation-induced marker in oral carcinoma increasing radiation resistance. J Oral Pathol Med. 2016;45(1):63-69.

12. Kudo Y, Iizuka S, Yoshida M, et al. Matrix metalloproteinase-13 (MMP-13) directly and indirectly promotes tumor angiogenesis. J Biol Chem. 2012;287(46):38716-38728.

13. Baker EA, Leaper DJ, Hayter JP, Dickenson AJ. The matrix metalloproteinase system in oral squamous cell carcinoma. Br J Oral Maxillofac Surg. 2006;44(6):482-486.

14. Cieplak P, Strongin AY. Matrix metalloproteinases - from the cleavage data to the prediction tools and beyond. Biochim Biophys Acta. 2017;1864(11 Pt A):1952-1963.

15. Tadbir AA, Purshahidi S, Ebrahimi H, et al. Serum level of MMP-3 in patients with oral squamous cell carcinoma - lack of association with clinico-pathological features. Asian Pac J Cancer Prev. 2012;13(9): 4545-4548.

16. Egeblad M, Werb Z. New functions for the matrix metalloproteinases in cancer progression. Nat Rev Cancer. 2002;2(3):161-174.

17. Shrestha B, Bajracharya D, Byatnal AA, Kamath A, Radhakrishnan R. May high MMP-2 and TIMP-2 expressions increase or decrease the aggressivity of oral cancer? Pathol Oncol Res. 2017;23(1):197-206.

18. Lee CH, Liu SY, Lin MH, et al. Upregulation of matrix metalloproteinase-1 (MMP-1) expression in oral carcinomas of betel quid (BQ) users: roles of BQ ingredients in the acceleration of tumour cell motility through MMP-1. Arch Oral Biol. 2008;53(9):810-818.

19. Monteiro LS, Delgado ML, Ricardo S, et al. Prognostic significance of CD44v6, p63, podoplanin and MMP-9 in oral squamous cell carcinomas. Oral Dis. 2016;22(4):303-312.

20. Yen $\mathrm{CY}$, Chen $\mathrm{CH}$, Chang $\mathrm{CH}$, et al. Matrix metalloproteinases (MMP) 1 and MMP10 but not MMP12 are potential oral cancer markers. Biomarkers. 2009;14(4):244-249.

21. Agha-Hosseini F, Mirzaii-Dizgah I. Serum and saliva collagenase-3 (MMP-13) in patients with oral lichen planus and oral squamous cell carcinoma. Med J Islam Repub Iran. 2015;29:218.

22. Agha-Hosseini F, Mirzaii-Dizgah I, Mahboobi N, Shirazian S, Harirchi I. Serum and saliva MMP-3 in patients with OLP and oral SCC. J Contemp Dent Pract. 2015;16(2):107-111.

23. Lotfi A, Mohammadi G, Tavassoli A, Mousaviagdas M, Chavoshi H, Saniee L. Serum levels of MMP9 and MMP2 in patients with oral squamous cell carcinoma. Asian Pac J Cancer Prev. 2015;16(4):1327-1330.

24. Feng X, Lin J, Xing S, Liu W, Zhang G. Higher IGFBP-1 to IGF-1 serum ratio predicts unfavourable survival in patients with nasopharyngeal carcinoma. BMC Cancer. 2017;17(1):90.

25. Kasprzak A, Kwasniewski W, Adamek A, Gozdzicka-Jozefiak A. Insulin-like growth factor (IGF) axis in cancerogenesis. Mutat Res. 2017;772:78-104

26. Brady G, O’Regan E, Miller I, Ogungbowale A, Kapas S, Crean SJ. Serum levels of insulin-like growth factors (IGFs) and their binding proteins (IGFBPs), -1, -2, -3, in oral cancer. Int J Oral Maxillofac Surg. 2007; 36(3):259-262.

27. Marimuthu A, Chavan S, Sathe G, et al. Identification of head and neck squamous cell carcinoma biomarker candidates through proteomic analysis of cancer cell secretome. Biochim Biophys Acta. 2013;1834(11): 2308-2316.

28. Schiegnitz E, Kammerer PW, Koch FP, Kruger M, Berres M, Al-Nawas B. GDF 15 as an anti-apoptotic, diagnostic and prognostic marker in oral squamous cell carcinoma. Oral Oncol. 2012;48(7):608-614.

29. Blatt S, Kruger M, Ziebart T, et al. Biomarkers in diagnosis and therapy of oral squamous cell carcinoma: a review of the literature. J Craniomaxillofac Surg. 2017;45(5):722-730.

30. Schiegnitz E, Kammerer P, Al-Nawas B. Quality assessment of systematic reviews and meta-analyses on biomarkers in oral squamous cell carcinoma. Oral Health Prev Dent. 2017;15(1):13-21.

31. Shen W, Xi H, Wei B, Chen L. The prognostic role of matrix metalloproteinase 2 in gastric cancer: a systematic review with meta-analysis. J Cancer Res Clin Oncol. 2014;140(6):1003-1009. 
32. Wang G, Wang W, Zhou J, Yang X. Correlation between telomerase activity and matrix metalloproteinases 2 expression in gastric cancer. Cancer Biomark. 2013;13(1):21-28.

33. Patel BP, Shah SV, Shukla SN, Shah PM, Patel PS. Clinical significance of MMP-2 and MMP-9 in patients with oral cancer. Head Neck. 2007;29(6): 564-572.

34. Agnihotri R, Crawford HC, Haro H, Matrisian LM, Havrda MC, Liaw L. Osteopontin, a novel substrate for matrix metalloproteinase-3 (stromelysin-1) and matrix metalloproteinase-7 (matrilysin). J Biol Chem. 2001;276(30):28261-28267.

35. Amalinei C, Caruntu ID, Balan RA. Biology of metalloproteinases. Rom J Morphol Embryol. 2007;48(4):323-334.

36. Andisheh-Tadbir A, Khademi B, Kamali F, Fattahi MJ, Malekzadeh M, Taghva M. Upregulation of serum vascular endothelial growth factor and matrix metalloproteinase- 3 in patients with oral squamous cell carcinoma. Tumour Biol. 2014;35(6):5689-5693.

37. Nielsen BS, Rank F, Lopez JM, et al. Collagenase-3 expression in breast myofibroblasts as a molecular marker of transition of ductal carcinoma in situ lesions to invasive ductal carcinomas. Cancer Res. 2001; 61(19):7091-7100.
38. Lederle W, Hartenstein B, Meides A, et al. MMP13 as a stromal mediator in controlling persistent angiogenesis in skin carcinoma. Carcinogenesis. 2010;31(7):1175-1184.

39. Bhatavdekar JM, Patel DD, Vora HH, Balar DB. Circulating markers and growth factors as prognosticators in men with advanced tongue cancer. Tumour Biol. 1993;14(1):55-58.

40. El-mezayen HA, Metwally FM, Darwish H. A novel discriminant score based on tumor-associated trypsin inhibitor for accurate diagnosis of metastasis in patients with breast cancer. Tumour Biol. 2014;35(3): 2759-2767.

41. Vasan RS, Sullivan LM, D'Agostino RB, et al. Serum insulin-like growth factor I and risk for heart failure in elderly individuals without a previous myocardial infarction: the Framingham Heart Study. Ann Intern Med. 2003;139(8):642-648.

42. Pollak MN, Schernhammer ES, Hankinson SE. Insulin-like growth factors and neoplasia. Nat Rev Cancer. 2004;4(7):505-518.

\section{Publish your work in this journal}

OncoTargets and Therapy is an international, peer-reviewed, open access journal focusing on the pathological basis of all cancers, potential targets for therapy and treatment protocols employed to improve the management of cancer patients. The journal also focuses on the impact of management programs and new therapeutic agents and protocols on

\section{Dovepress}

patient perspectives such as quality of life, adherence and satisfaction. The manuscript management system is completely online and includes a very quick and fair peer-review system, which is all easy to use. Visit http://www.dovepress.com/testimonials.php to read real quotes from published authors. 